deal with, but is also without prejudice to, questions such as the liability of States and their nationals, the polluter-pays-principle, the precautionary principle, common but differentiated responsibilities, and the transfer of funds and technology to developing countries, including intellectual property rights.

(b) The topic will also not deal with specific substances, such as black carbon, tropospheric ozone, and other dual-impact substances, which are the subject of negotiations among states. The project will not seek to 'fill' the gaps in the treaty regimes.

(c) Questions relating to outer space, including its delimitation, are not part of the topic.

(d) The outcome of the work on the topic will be a set of draft guidelines that do not seek to impose on current treaty regimes legal rules or legal principles not already contained therein.

(e) The special rapporteur's reports would be based on this understanding (Official Records of the General Assembly, Sixty-eighth Session, Supplement 10, Doc. A/68/10, para. 168).

Shinya Murase

doi:10.1093/yiel/yvu051

\title{
8. International Maritime Organization (IMO)
}

\section{(1) General}

The Assembly of the IMO met for its twenty-eighth session in London from 25 November to 4 December. At this meeting, the Assembly elected the following states to be members of its Council for the period 2014-15:

- Category (A): ten states with the largest interest in providing international shipping services: China, Greece, Italy, Japan, Norway, Panama, Republic of Korea, Russian Federation, United Kingdom, and the United States;

- Category (B): ten states with the largest interest in international seaborne trade: Argentina, Bangladesh, Brazil, Canada, France, Germany, India, Netherlands, Spain, and Sweden;

- Category (C): twenty states not elected under (A) or (B) above, which have special interests in maritime transport or navigation and whose election to the Council will ensure the representation of all major geographic areas of the world: Australia, Bahamas, Belgium, Chile, Cyprus, Denmark, Indonesia, 
Jamaica, Kenya, Liberia, Malaysia, Malta, Mexico, Morocco, Peru, Philippines, Singapore, South Africa, Thailand, and Turkey.

The IMO Council met twice in 2013 (at its $110^{\text {th }}$ session on 15-19 Jul and its $111^{\text {th }}$ session on 4 December). At its $111^{\text {th }}$ session, parties endorsed the restructuring of the IMO sub-committees, reducing their numbers from nine to seven. The new sub-committees include:

- the Sub-Committee on Human Element, Training and Watchkeeping (HTW);

- the Sub-Committee on Implementation of IMO Instruments (III);

- the Sub-Committee on Navigation, Communications and Search and Rescue (NCSR);

- the Sub-Committee on Pollution Prevention and Response (PPR);

- the Sub-Committee on Ship Design and Construction (SDC);

- the Sub-Committee on Ship Systems and Equipment (SSE); and

- the Sub-Committee on Carriage of Cargoes and Containers (CCC) (for further information, see $<$ http://www.imo.org $>$ ).

(2) New Instruments and Developments

\section{(A) Mandatory Audit Scheme}

The Assembly adopted a series of amendments and new instruments to give effect to a new mandatory audit scheme as a tool for assessing member states' performance of their obligations and responsibilities as flag, port, and coastal states under IMO treaties. Measures adopted giving effect to this new scheme included the IMO Instruments Implementation Code (III Code); the Framework and Procedures for the IMO Member State Audit Scheme; the 2013 non-exhaustive list of obligations under instruments relevant to the III Code; and a resolution on transitional arrangements from the voluntary to the mandatory scheme. The Assembly also adopted amendments to the following treaties to give effect to the scheme: the 1966 International Convention on Load Lines; the 1969 International Convention on Tonnage Measurement of Ships; and the 1972 Convention on the International Regulations for Preventing Collisions at Sea. Further amendments to other treaties to enhance the audit scheme are foreshadowed for 2014.

(B) Amendments to the 1996 Protocol to the Convention on the Prevention of Marine Pollution by Dumping of Wastes and Other Matter (London Convention)

Amendments to the London Protocol to the 1972 London Convention were agreed by parties to this convention at a meeting held at the IMO headquarters in London on 14-18 October. The amendments will enter into force sixty days after two thirds of the contracting parties have deposited an instrument of 
acceptance of the amendment with the IMO. The amendments regulate marine geo-engineering, including ocean fertilization.

The amendments to the protocol include a new Article 6bis, which provides that '[c]ontracting Parties shall not allow the placement of matter into the sea from vessels, aircraft, platforms or other man-made structures at sea for marine geoengineering activities listed in Annex 4, unless the listing provides that the activity or the sub-category of an activity may be authorized under a permit.' Marine geo-engineering is defined as 'a deliberate intervention in the marine environment to manipulate natural processes, including to counteract anthropogenic climate change and/or its impacts, and that has the potential to result in deleterious effects, especially where those effects may be widespread, longlasting or severe.'

A new Annex 4 on marine geo-engineering lists 'ocean fertilization,' which is defined as 'any activity undertaken by humans with the principal intention of stimulating primary productivity in the oceans. Ocean fertilization does not include conventional aquaculture, or mariculture, or the creation of artificial reefs.' Pursuant to the new annex, ocean fertilization activity may only be considered for a permit if it constitutes legitimate scientific research taking into account any specific placement assessment framework. In considering applications contracting parties must consider advice on proposals for activities listed from independent international experts or an independent international advisory group of experts (for further information, see < http://www.imo.org/OurWork/ Environment/LCLP/EmergingIssues/Pages/default.aspx $>$ ).

\section{(C) New Chapter 4 to Annex VI of the International Convention for the Prevention of Pollution from Ships (MARPOL Convention)}

A new chapter 4 of Annex VI of the MARPOL Convention, which mandates the Energy Efficiency Design Index for new ships and the Ship Energy Efficiency Management Plan for all ships, entered into force on 1 January. This is a nonprescriptive, performance-based mechanism that leaves the choice of technologies to use in a specific ship design to industry. Provided the required energyefficiency benchmarks are met, ship designers and builders are free to use the most cost-efficient solutions for the ship to comply with the regulations (for further information, see <http://www.imo.org/OurWork/Environment/Pollution Prevention/AirPollution/Pages/Default.aspx $>$ ).

\section{(D) Revised Garbage Rules for Vessels Enter into Force}

Revised Annex $\mathrm{V}$ regulationsfor the prevention of pollution by garbage from ships under the MARPOL Convention entered into force on 1 January. Annex V of the MARPOL Convention deals with garbage from vessels. The revised Annex $\mathrm{V}$ prohibits the discharge of all garbage into the sea except for certain limited exceptions provided for in the regulations (for further information, see 
$<$ http://www.imo.org/OurWork/Environment/PollutionPrevention/Garbage/ Pages/Default.asp $>$ ).

(3) Marine Environment Protection Committee (MEPC)

The MEPC met for its sixty-fifth session on 13-17 May in London. At this meeting, the MEPC continued its work on developing energy efficiency regulations; adopted the Resolution on the Promotion of Technical Co-operation and Transfer of Technology Relating to the Improvement of Energy Efficiency of Ships; and gave approval to carry out an update to the greenhouse gas (GHG) emissions estimate for international shipping. The MEPC also approved, with a view to subsequent adoption, draft amendments to the 2008 nitrous oxide technical code, which concerns the use of dual-fuel engines (for further information, see <http://www.imo.org/MediaCentre/MeetingSummaries/MEPC/Pages/ MEPC-65.aspx $>$ ).

\section{(4) Maritime Safety Committee (MSC)}

The MSC met for its ninety-second session on 12-21 June at the IMO's London headquarters, and its work covered a range of measures including the adoption of amendments to the International Convention for the Safety of Life at Sea (SOLAS Convention) relating to passenger drills. The MSC also discussed recommendations arising from the Costa Concordia incident; piracy and armed robbery against ships; and endorsed a restructuring of the MSC sub-committees, reducing the number of subcommittees from nine to seven (for further information, see <http://www.imo.org/MediaCentre/MeetingSummaries/MSC/Pages/ MSC-92nd-session.aspx $>$ ).

\section{(5) Legal Committee}

The $100^{\text {th }}$ session of the Legal Committee was held on 15-19 April. At this meeting, the Legal Committee, inter alia, endorsed guidelines to assist countries in meeting reporting requirements under the 2010 International Convention on Liability and Compensation for Damage in Connection with the Carriage of Hazardous and Noxious Substances by Sea. These guidelines are expected to help overcome difficulties with complying with reporting requirements, which has been one of the main reasons many states have not yet ratified the protocol (for further information, see < http://www.imo.org/MediaCentre/MeetingSumma ries/Legal/Pages/LEG-100th-session.aspx $>$ ). 